\title{
Organizational Memory and Forgetfulness Generating Vulnerabilities in Complex Environments
}

\author{
Robson Quinello* \\ E-mail address: rquinello@ig.com.br \\ Fundação Escola de Comércio Álvares Penteado - FECAP \\ São Paulo, SP, Brazil
}

\begin{abstract}
This article analyzes the relationship between organizational memory and forgetfulness in the generation of operational vulnerabilities, based on a case study carried out with a highly specialized technical team from a multinational company of the automotive sector. The article starts with the presentation of the complexity context of the Brazilian automotive sector in the last decades. It then goes on to discuss the theoretical referential on learning organizations, organizational memory and forgetfulness and organizations with high operational reliability characteristics. Finally, a case study is presented, carried out based on the theoretical concepts described in the body of the article, showing the contradictions and evidence of this relationship.
\end{abstract}

Key words: learning organizations; learning process; errors; human failures; forgetfulness process; organizational memory.

Received 09 June 2005; received in revised form 29 August 2005.

Copyright (C) 2006 Brazilian Administration Review. All rights reserved, including rights for translation. Parts of this work may be quoted without prior knowledge on the condition that the source is identified.

* Corresponding author: Robson Quinello

Av. Francisco Gonçalves de Andrade Machado, 81, Apto 125, Paraíso, São Paulo, SP, 01323-050, Brazil. Tel.: +55 119791 7209; +55 113284 3020; fax: +55 1141749872. 


\section{INTRODUCTION}

The organizational paradigm underwent deep changes in the $20^{\text {th }}$ century. Total Quality Management (TQM) was a movement towards quality which penetrated the organizations from 1980 onward (mainly in the American automotive sector) and, among the benefits already known, such as the increase in quality of products and services and the concern for customers, it brought awareness of the need for developing team work, also known as work cells. The decision-makers began to understand that the answers to many problems were often found in the lower positions, known in Japan as Quality Circles (Ishikawa, 1998). During the 1990s, the Organizational Re-Engineering arose with the decrease and approach of the hierarchical positions, facilitating the communication channel between the operational and the strategic levels (Robbins, 1999). At the end of the $20^{\text {th }}$ century, the concept of the Learning Organization was spread over the companies, which, with the competence and knowledge stored through the time, could learn and seek for competitive advantage.

However, we witness more and more repeated scandals, often tragic, in the corporate world. Intent on maximizing profits and results, companies such as Enron, Petrobrás, Merck, GM, NASA and Union Carbide, among others, made strategic 'déjà $v u$ ' errors which have been widely examined by many authors. The purpose of this work is not to show the strategies (correct or not) of these companies, nor to question their ethical and political positions. This work aims to observe details of the cognitive structure mechanism that would lead these companies to lose memory, causing forgetfulness and increasing their operational vulnerability. In Brazil, the current literature on organizational behavior has not greatly explored this process within the so-called learning organization.

This paper starts off with the presentation of the complexity context of the Brazilian automotive sector in recent decades. In item 3, we will find the theoretical referential on the learning organization and the organizational learning process in highly complex organizations. In item 4, studies on neuroscience will be approached, specifically on the memory and forgetfulness of individuals. In item 5, a case study applied to a technical team of a multinational company of the automotive sector, located in the Greater São Paulo Metropolitan Area, State of São Paulo, was carried out to understand the reason for recurrent unexpected events (operational errors or failures). Would it be possible, as in Morgan's metaphor, for the companies to be considered as brains and also to have the side effects of collective forgetfulness? Would organizational errors and failures be exploited as much as success? Why not exploit the Worst Practices as well as the Best Practices? Would the organizational culture of this organization be prepared for the Learning Organization? How are the organizations affected by organizational memory? What is the relationship between ethics and vulnerability?

\section{THE AUTOMOTIVE INDUSTRY}

At the end of the Second World War, American industries began an attempt to satisfy the huge demand for consumer goods which, for almost 20 years, had faced no significant competition. The administrative methods grew and improved, while on the other side of the Pacific, the Japanese people sought out Deming to teach them such Quality Management methods. According to them, the product, even in the hands of the consumer, undergoes development (Sholtes, 1992).

Toyota's organization model, also called ohnoism after an influential Chief Executive, broke with the traditional model and presented four important characteristics: a) team or cell work, b) autonomy for working groups, c) reduction of hierarchical levels, and d) functional re-approach within companies. This approach, divulged under the name TQM in the U.S.A., was expounded by the Statistician W. Edwards Deming, who developed many of his theories during the Second World War, when he taught industries how to use statistical methods to improve the quality of army production. The valuable cooperation of Joseph Juran and Philip Crosby should not be forgotten, in addition to the 
great contributors such as Feigenbaum, Conway and the specialists Taguchi, Ishikawa and Shingeo Shingo over the ensuing decades (Pike \& Barnes, 1996).

The automotive industry is one of the most important industrial activities for the generation of employment, income and products. Japanese industrial reconstruction, which grew significantly in the 1950s through Total Quality Control (TQC), made relevant changes to the industrial production systems in general, and more specifically, in the automotive sector, the most divulged and known as Toyota Production System (Shingo, 1996). Basically, this model had as an assumption more flexible mass production of differentiated articles, including operations based on new development, quality and productivity concepts, revolutionizing the fordist division of labor, where the polyvalent and autonomous worker (Hirata as cited in Lima et al., 2002) played a fundamental role. For this system to be effective, Shingo (1996) reinforced the role of the industrial maintenance processes in eliminating breakdown and defects of machinery and equipment. Zero-defects or poka-yoke mechanisms were improved in order to avoid unexpected stoppages.

With the excellent results achieved by the Japanese industry and its subsequent entry into the American market in the 1980s, the local industry reacted and imitated the process (created by it), extending the practices to its European, Asian and Latin-American branches. For this model to succeed, the European, and especially the American companies, adopted new positions in relation to their suppliers and buyers, i.e., involving all agents of the value chain of the industry, starting a complex process of implementation of interdependence systems and transfer of innovation of a technological and organizational nature, aimed at self-support through shared risks, i.e., long-term self-support. This new model was opposed to the fordist model when applying concepts from independent suppliers and competitors. The basis of this new standard of relationship is the use of managerial techniques, such as kanban (printed cards that contain specific information such as quantity and replenishment), just-in-time (aims to attend demand promptly, with quality and no waste) and kaizen (a range of procedures that aim for continuous process improvement) (Castro, 1993).

In Brazil, (Anfavea, 2004; Iedi, 2004; Lima et al., 2002) the movement towards quality in the current conceptions arrived in the 1990s, when incentives to the segment were intensified with the 1996 Brazilian Automotive Regime. This program, which included a government policy strategy, drew up different phases and economic policy instruments aiming for more competition among already established companies and also stimulating competition by stipulating rules and incentives to foreign ventures. The main point of this policy already included a focus in the long-term for the sector to increase exports, with gradual concessions to imports. In 1997, for example, the Government decided to direct the investments of the sector to under-developed regions (North, Northeast and Mid-west) to accelerate growth and decentralize the sectorial production at the same time.

\section{(UN)LEARNING ORGANIZATIONS}

In the late $20^{\text {th }}$ century, the concept of Learning Organizations entered the academic and, afterwards, the corporate world. According to Robbins (1999), a learning organization is able, as well as the individuals, to develop the ability to adapt and change. These organizations, whether aware or not, learn (one more than the others). According to Senge (1998), the Fifth Discipline is an organization which, through its members, improves the capacity to create a glowing future, irrespective of the technology development, which is only a means to exchange information. Senge (1998) points out that, "one person may even obtain more information thanks to technology, but if this person does not know how to use it, it will not help" (p. 83). He outlines five basic characteristics of a learning organization:

1. Shared visions among the members of the company;

2. Suspension of old assumptions and freely thinking together to solve problems;

BAR, v. 3, n. 1, art. 5, p. 64-78, Jan./June 2006

www.anpad.org.br/bar 
3. The members understand that all the processes and activities of the organization are linked;

4. Open communication among people in all hierarchical positions, with no fear and punishment;

5. Examination of the whole system rather than attempts to fix isolated problems.

Burgoyne (2003) denominates these companies Learning Organizations and considers them dynamic systems that are capable of changing themselves to satisfy objectives and targets closer to the desires of the interested parties. These learning companies incorporate into their essences, most probably due to a strategy deliberated by senior management, characteristics of the organizational learning process, which were widely divulged following the movements towards quality in the 1980s. However, the organizations of excellence were unable to maintain the status for a long time, because they were unable to adapt and learn. Actually, much of what was learned was only a legitimation exercise in the face of pressures from competition among the organizations. According to Deming (1980), the TQM stated the active participation of the quality circles, composed of employees who were to interact with actions and decisions of day-to-day problems and the development of improvement and continuous learning.

\section{Learning to Learn Process: Organizations considered as Brains}

According to Morgan (1996), while the economy is based on knowledge, where information, knowledge and learning are key elements in what is called the new digital era, we can draw a parallel between the performance of the organizations and our brain. Lab experiments have shown that brains are based on growing refinement and not on cause and effect chains. There would be a parallel with the holograph, where the brain would be capable of building the whole of realities, from pieces or their parts. This study questions the paradox of the brain in being holographic and specialized at the same time, showing that an intelligent action may arise from almost independent processes, by merely following some basic rules. The assumption is that the organizations are information and communication systems and decision-makings, i.e., they are also information processors. Another aspect is that with the new IT decentralizing capacities, the process also transforms the organizations model. The electronic evolution and the intelligence networks, together with current microprocessors, facilitate the appearance of the so-called virtual organization, where the concept of the physical has changed. The introduction of just-in-time and e-commerce systems created a scenario which up to that point was only found in scientific fiction.

The challenge now is to create complex systems which are able to learn just as the brain does. With cybernetics, it is possible to understand the process of information exchange in the machine and learn the negative feedback concept, i.e., a self-regulating system that operates under operational rules or guidance standards. This system has to sense, detect and monitor the environment, list the information, detect deviations and start a corrective action (Morgan, 1996; author's emphasis). This process would have a mechanism called single circuit learning, which differs from the double circuit only in the questioning, i.e., in the second type there is the self-questioning of the actions that enable the learning to learn. 
Figure 1: Single and Double Circuit Learning



Source: Morgan (1996, p. 92).

Figure 1 shows the process of learning in single or double circuit (in this case, step 2 a.). The organizations need to understand how they reinforce the learning in single circuit, i.e., without selfquestioning, According to Morgan (1996), the companies basically utilize three types of systems:

1. Budgets and other administrative controls that maintain a single circuit learning, monitoring the situation, but jeopardizing the learning process because they are far too bureaucratic;

2. Bureaucratic systems that tend to halt the questioning process due to their strict hierarchical structures;

3. The process of rendering accounts and other awards that encourage the employees to escape from reality and mask the real situation of the organization (author's emphasis).

Morgan suggests that the use of the double circuit is a step towards searching learning organizations, They need to stimulate questioning, foresee changes and allow an organization standard and strategic directions. These organizations, such as Apple, CNN and Canon, to mention only a few, were able to redefine themselves over time, anticipating environmental changes and creating uncertainties to reach new development standards. The power to operate in single circuit is such that many quality programs failed to subjugate the continuous learning and the power of questioning. The managers of the double circuit must be open to uncertainties in order for new standards to arise.

The opening to question of the current rules may be achieved with the use of ringi, a system by which organizational guidelines go through the local community so that, through disagreement, an agreement is reached. This method allows for self-questioning and corrective and preventive actions. Conflicts are generated when challenging rules, since they change the current standard, and the development of abilities is fundamental in managing this environment. According to Morgan (1996), to tell what one should not do, using the ringi and selecting the limits to reach the targets are attitudes that challenge the modern administration. In the metaphor proposed by the author, the same capacity of regeneration, self-organization and learning of the brain is found in organizations. For example: companies that lost employees in disasters or dismissals were able to re-create themselves through the absorption of new standards. This shows the learning capacity of the organization.

\section{Unlearning Organization}

Based on the same assumption of Morgan's that organizations (metaphorically considered as brains) can learn, they are vulnerable and exposed to the unlearning process. In the double circuit, step 2a (see Figure 1), some companies with strong bureaucratic structures would not stimulate self-questioning of processes and activities because this mechanism could expose the power structure to risk. As highlighted by March and Simon (1975), "all human process of decision-making, either intimate or in 
the organization, deals with the discovery and selection of satisfactory alternatives; only under special cases, it is concerned about the discovery and selection of optimal alternatives" (p. 198). This observation reinforces the argument that the decision-making power (step 2 a, i.e., questioning) goes through the individual level. The answer given to a certain problem may not exactly be the ideal. Therefore, it is subject to error or failure. Accordingly, error or failure are not well accepted in the organizational culture, mainly in the organizations known as High Reability Organizations (HRO), i.e., organizations that expose human lives.

Among them, we cite the nuclear, chemical, petrochemical, automotive, spatial, food and pharmaceutical sectors, and others (Weick \& Sutcliffe, 2001). The characteristics of the attentive HRO are: concern about failures and comprehensive general liability, encouragement to report errors, resistance to simplifying interpretations, operational sensitivity, commitment to recovery and concern about competence and technical ability. An example of a department with strong HRO characteristics is the maintenance department, since it is more vulnerable to unexpected events, in addition to its capacity for generating and solving unusual problems. According to the authors, a learning organization, concerned with unexpected events, considers the maintenance area as a strategic focus, due to its capacity for finding failures during stages preceding the event and would, currently, increase due to the introduction of more complex technologies to the equipment, the increase in items in internal procedures and operational pressures. Recent examples of accidents directly or indirectly involving maintenance are the sinking of the Russian nuclear submarine Kursk in 2000, the American Spaceship Columbia in 2003, the Brazilian petroleum platform P36 in 2001, to name a few, due to serious operational failures culminating in crises (Agência Estado, 2004; Folha Online, 2004; Weick \& Sutcliffe, 2001). According to the authors, non-compliance with the elements mentioned above caused the chemical disaster of Union Carbide in 1984 (Bhopal, India) and of the American spaceship Challenger in 1986, which killed 7 astronauts. Some of the topics mentioned were neglected, resulting in unexpected events (some recurrent events). One of the biggest problems reported by Weick and Sutcliffe is the candidate to report the error. This person needs confidence and reliability, and these characteristics are difficult to construe and establish, but easily destroyed. Here the stimulated organizational culture in the organization is a critical factor for the HRO. A secure organization is an organization that is informed, and this depends, according to the authors, on some organizational subcultures (characteristics) such as: reporting culture, i.e., what should be reported when an error or a near error occurs; just culture, i.e., how the responsibility in case of human error or near error will be approached; flexible culture, how people adapt to pressures and increasing changes, and learning culture, how effective people will be at converting the lessons they have learned into the reconfiguration of procedures and actions.

Since our society is excessively focused on successful cases, the organization hardly and rarely exposes its weaknesses, errors or failures, making the learning process that presupposes the feedback of the positive and negative aspects difficult. This pressure to succeed may occur by the mechanism of coercion and in the microsocial dimension, where individuals can be encouraged not to report errors or failures due to fear or in convenience. Accordingly, Pfeffer (1997) challenges managers and decisionmakers to understand the organizations not through the best practices, but also through the worst practices.

The learning process seldom occurs without errors, since it is a system of information processing with limited capacity according to the available cognitive resources (Garcia-Marques, 2000). Errors become an integral part of the learning process. With this argument, Downs (2001) reported a study carried out in a group of trainees subdivided into five groups. Each group was gradually exposed to a set of names of relatively well-known villages and names of counties that were not very well-known. Each group would have a different time frame for learning and checking. They should correlate the names to the villages and the scores would be computed. It was assumed that age and time of exposure to the information would be directly correlated to the level of score. However, the study showed that it was not necessarily the group of oldest people who scored highest, showing that errors are often correlated not to experience, but to the process of routine of tasks which, frequently, alienates the employees. 


\section{ORGANIZATIONAL MEMORY AND FORGETFULNESS}

Memory is the power or process of reproduction or recovery of what has been learned or retained, mainly through associative mechanisms, and can be classified into 3 different types (Croasdell, 2001, p. 8):

1. episodic - also known as individual memory and reflects knowledge acquired by individual experiences (memory episodes);

2. semantic - factual knowledge (historical fact);

3. procedural - contains abilities that will be acquired for the learning (for example, a swimming manual).

The organizations use information systems to store the individual experiences that are constantly requested and shared to understand and anticipate the events. According to Croasdell (2001) "all new knowledge generates a disturbance in the system" (p. 9) and memory influences the individual behavior because it provides insight for solving problems and decision-making. It serves as a reference for understanding human activities, since it is associated with collective memory (one of the factors that help create the model for an automatic memory system). Accordingly, this whole system helps in the recollection of the applicability of knowledge and this, in the creation of efficiency and productivity. Machado-da-Silva, Fonseca and Fernandes (2000) highlight that the process of solving problems:

[...] may not necessarily occur according to environmental experiences; [...] the accumulation of difficulty; repetition of errors or the event of serious problems may lead to radical contestation of the paradigm, generating changes of a fundamental nature (p. 134).

The organizational memory is a generic concept that describes storage, representation and sharing of knowledge, culture, power, practices and policy within an organization. Its purpose is to reduce the costs of transaction, the speed of access to past practices and solutions, help in decision-making, share of knowledge among the working members and teams and the reduction of the dependency of the organization in relation to individuals (in case of turnover). If this memory is easily lost or almost useless, it will not help the organization to seek competitive advantages, develop the organization learning concept and increase autonomy and competencies for sudden changes in the market (Croasdell, 2001).

Hodge, Anthony and Gales (1996) highlight that for the information management systems, two factors are critical in organizations: validity and reliability. The authors add that "[...] the organizations are basically information processors [...] used for decision-making on what and how to do or not to do things" (p. 296).

\section{UNEXPECTED EVENTS: THE CASE}

In order to analyze the process of organizational memory and forgetfulness in generating organizational vulnerabilities, a case was chosen from the industrial maintenance department of a company of the automotive sector located in the Greater São Paulo Metropolitan area, State of São Paulo in 2004. The industrial maintenance of this organization is responsible, among other activities, for making available $100 \%$ of the supply of compressed air, electrical energy, water and gas to the 
production process of the plant. Non-compliance may cause a stoppage in production and, consequently, the products will not be manufactured.

In order to demonstrate the degree of dispersion when making a decision in a time of crisis, a questionnaire was prepared containing ten possible random actions during a crisis and 28 maintenance technicians were requested to number them in order of importance (1 being the most important action and so on) during an unexpected event.

They answered the questionnaire and the result was as follows:

\section{Chart 1: Suggested Actions in Order of Importance}

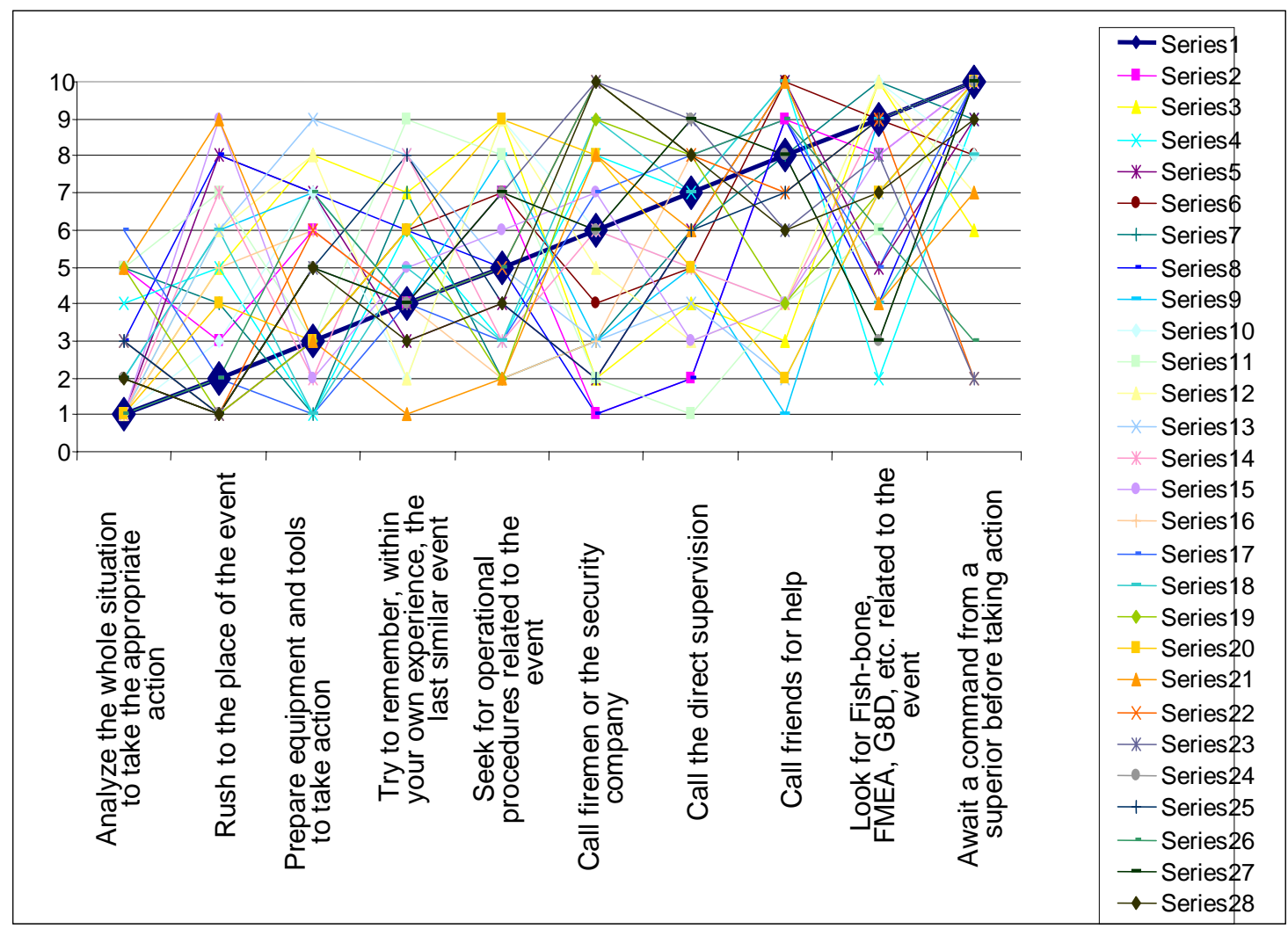

Source: authors.

The machine bureaucracy (Mintzberg, 1995) depends primarily on the standardization of its operating work processes. The basic structure is defined by the author:

[...] highly specialized, routine operating tasks; very formalized procedures in the operating core; a proliferation of rules, regulations, and formalized communication throughout the organization; largesized units at the operating level; reliance on the functional basis for grouping tasks; relatively centralized power for decision making; and an elaborate administrative structure with sharp distinctions between line and staff".art 1 shows many different answers among the technicians, i.e., during an unexpected event, few of them would act the same way. After this analysis, the scores given in each activity by the technicians were summed up and a standard order was achieved (bold line in chart 1) (p. 164-165).

In order to show the unlikeness of the answers, a similarity analysis was prepared using the SPSS software and only three pairs were found with similar replies. 
Chart 2: Similarity Analysis

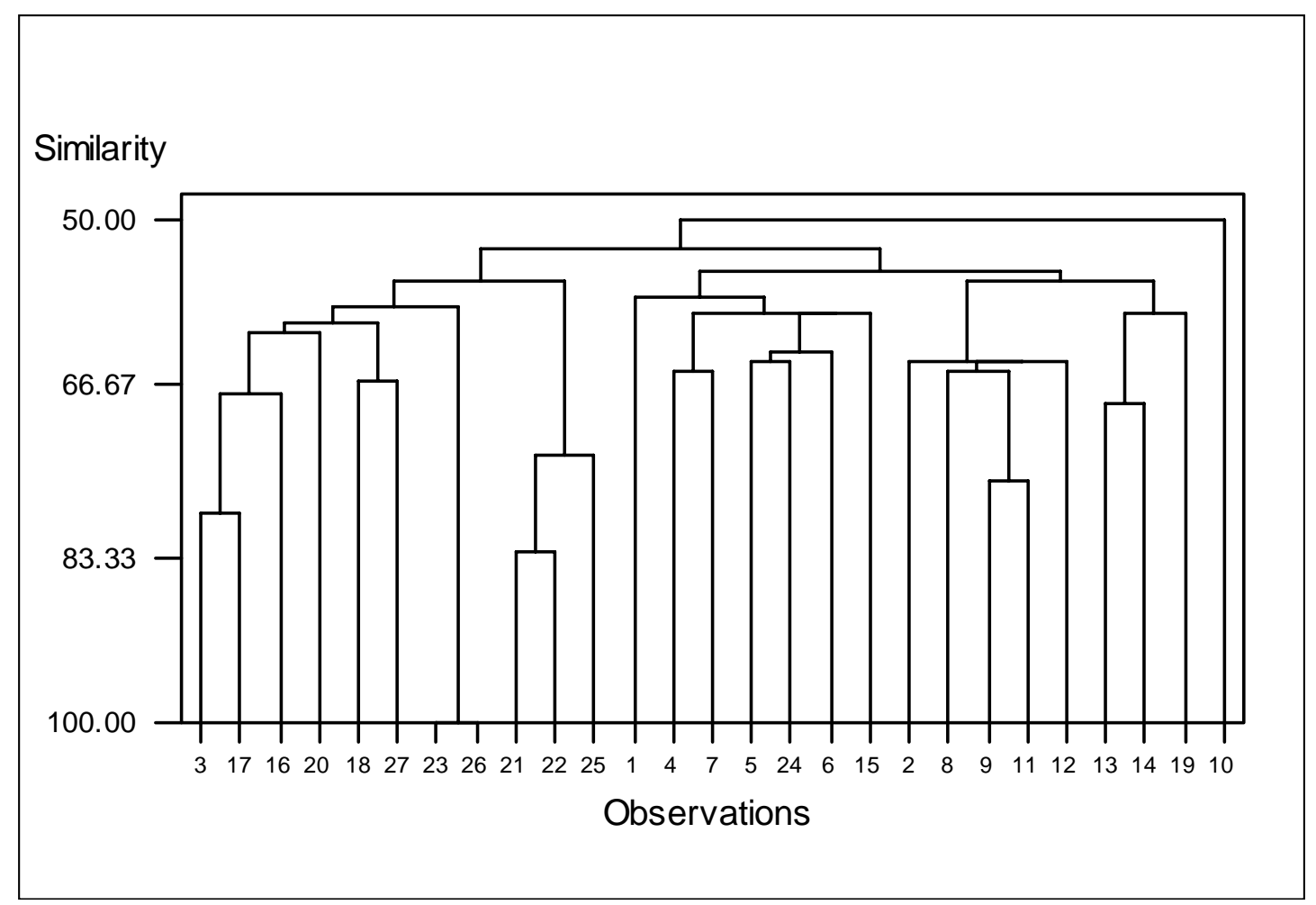

Source: prepared through SPSS.

In the similarity analysis, we verified that only three pairs of technicians presented approximately $80 \%$ similarities, again showing the different attitudes taken before the crisis. During another phase of the analysis, the grouping of similar questions was verified.

\section{Chart 3: Clusters Analysis of the Elaborated Questions}

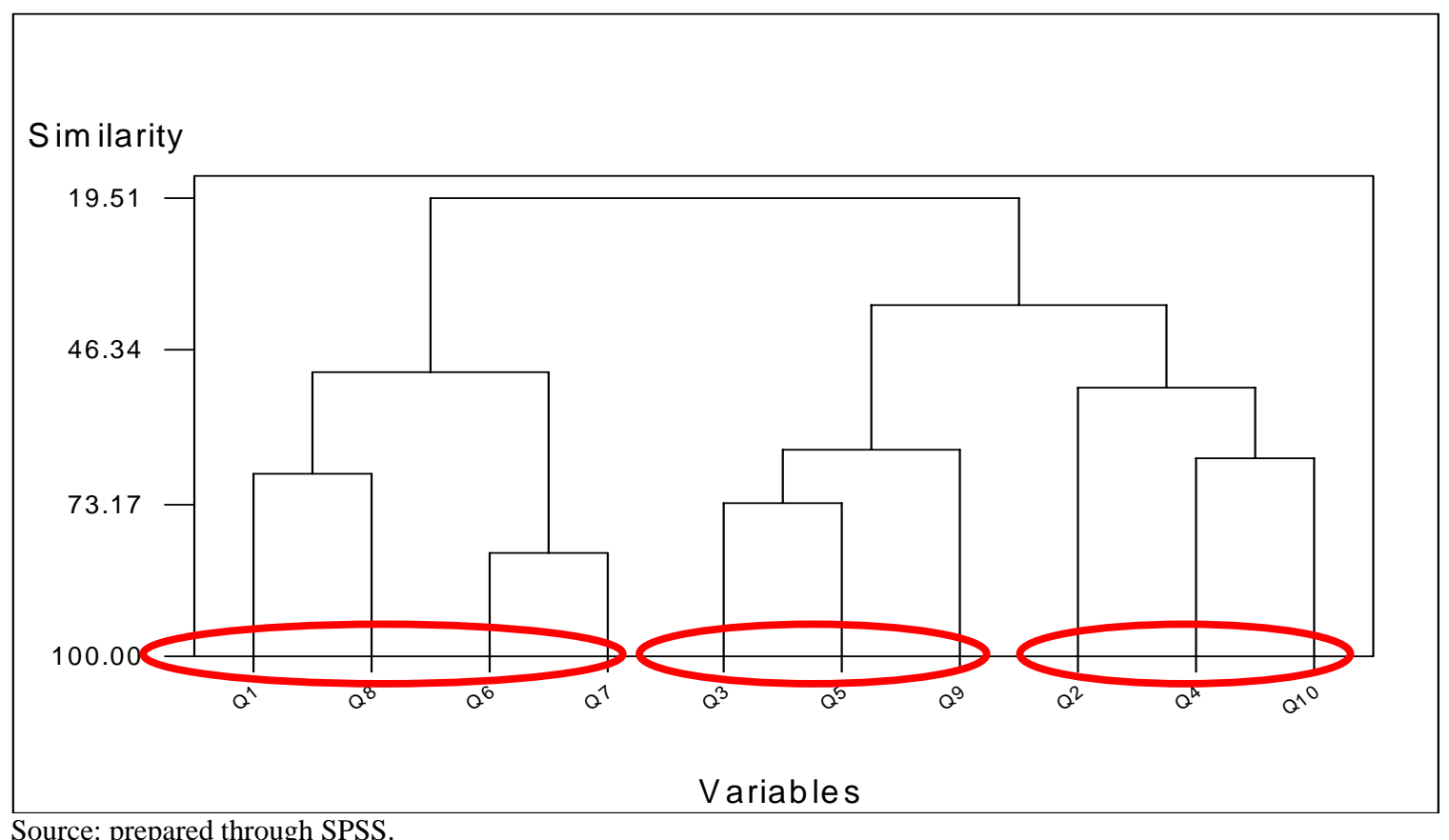

Source: prepared through SPSS. 
It is concluded that actions 1, 8, 6 and 7 are what we call Environmental Memory, i.e., in this group, the evoked actions are external and would depend on the action of others. The second group, formed by actions 3,5 and 9, we denominate procedural memory, where the actions evoked by the technicians are written through rules, procedures and manuals. In the last cluster, we find questions 2 , 4 and 10, which we denominate individual memory, i.e., the technicians act according to their personal knowledge and experience.

The organizational forgetful process occurs due to the repression made by the organizations against failure. Izquierdo (2004) points out that "oftentimes, we are obliged to discard a memory immediately and replace it by another completely opposite” (p. 53). In the same way that individuals are able to repress memories whose evocations are harmful to the results, the organization (formed by individuals) would apparently have the same capacity. Garcia-Marques (2000) adds that in the social cognition schemes, it is possible to find automatic and controlled procedure. In complex environments, these processes may collide with each other. In case of an unexpected event, the cognitive mechanism can be automatic, while in unexpected events the individual may try the non-automatic procedure, which will consume a greater quantity of cognitive resources. These, however, are limited within the machine bureaucracy. In experimental psychology, as defined by Izquierdo (2004, p. 100), the process shown above is called reversal learning. For example, the case of laboratory rats that are stimulated to go through a labyrinth to find water. Once they learn, they will always follow the same route. One day, shocks were applied when they reached the end of the labyrinth. This action made them forget the labyrinth and learn not to go through it (they became disoriented). Making a comparison with this study, it is verified that at the time of the event (machinery stoppage), the shock glimpsed by future reprehensions leads the technicians to forget the standardized schemes and search for other means to solve the problems. It was also observed, that the difficulty to train teams in emergency simulations and the lack of efficient control behavior mechanisms by the technicians aggravate performance during the crisis. This phenomenon requires in-depth studies.

According to Cunha and Cunha (2000), improvisation is the object of neglected study in organizational science studies, but it is often used to solve problems. When analyzing the data relating to the events, one can model the process found during unexpected events: 
Figure 2: Mechanisms to Access the Organizational Memory

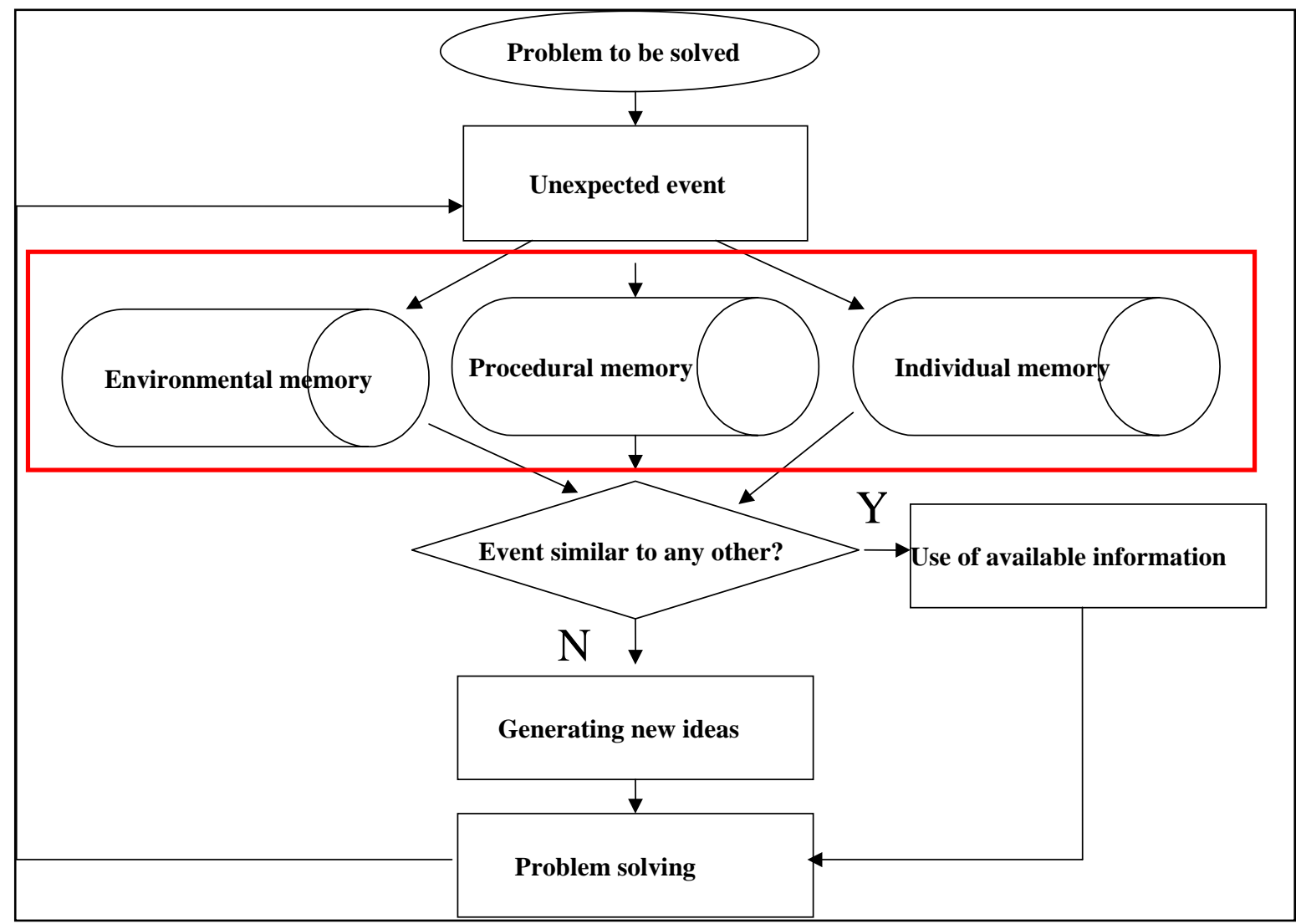

Source: authors.

Figure 2 illustrates, in a simple way, the access mechanism to environmental, procedural or individual memory. During an unexpected event, the individuals of the analyzed department activate the memories at random. This memory will contain past information (historical) to search for any similarity to the new event. If this event is recurrent, we use the information to solve the problem. If the event is new, the team will establish new actions and ideas which will, then, supply the repository with memories. The problem is that the evocation of these memories occurs at random and unpredictably, i.e., each individual of the maintenance department, in a time of crisis, activates a certain type of memory. This high disparity in the process of choosing generates operational vulnerability, since actions cannot be controlled.

With high variability in decision-making, the event may generate serious crises such as accidents or tragedies, as broadly demonstrated in the literature. It is possible to see, in Figure 3, that the accessed information is not always the most relevant: 
Figure 3: Significant Information

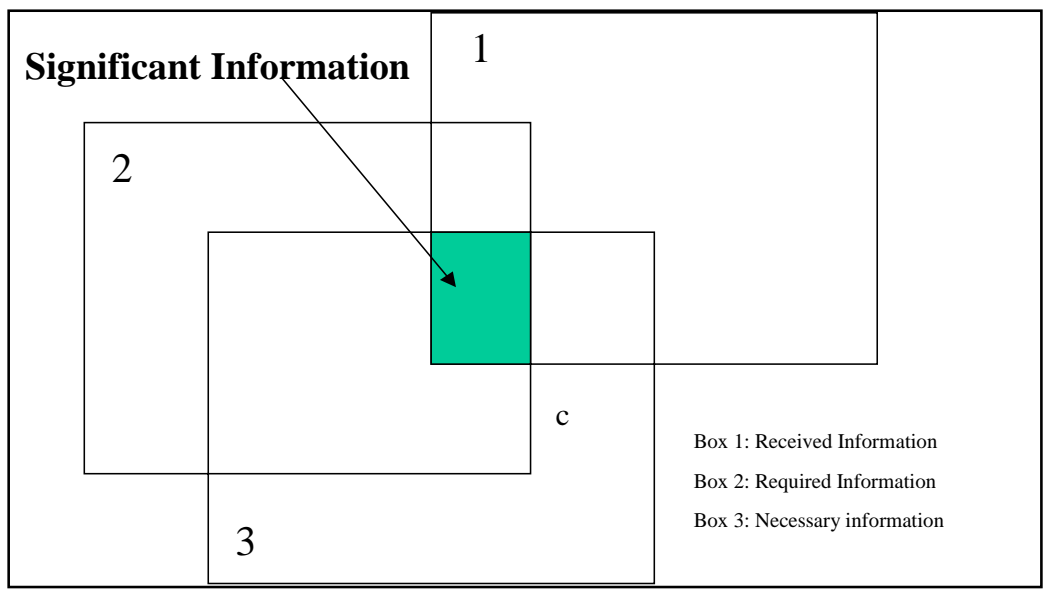

Source: Hodge et al. (1996, p. 302).

The process of decision-making in the case under analysis seems to search information that is not always within the painted area in Figure 3, where significant information is found, while immaterial information remains in the process of decision-making the more vulnerable the organizations become. Despite the need for in-depth empiric studies, there is evidence that ethics and vulnerability would have an inverse correlation in highly technical and complex environments.

\section{Figure 4: Correlation between Ethics and Vulnerability}

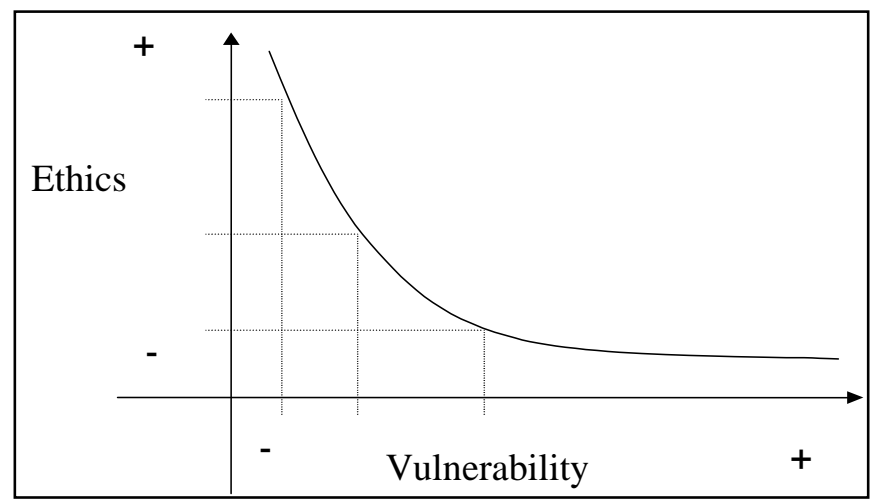

Source: authors.

It is noted in Figure 4 that when the ethics factor increases in decision-making, the vulnerability variable decreases. When this level of tolerance varies a great deal, dissimulation and conflicts are induced in the groups, and, in some cases, generate crises. This argument confirms the argument of Chatman and Cha (2003, p. 20-34) where the authors conclude that: a) leaders should frequently review their own behavior to evaluate the signals they are sending to the team members; b) when a leader seems to violate the organizational culture, even apparently, the employees consider this attitude to be a serious fault, coming from someone who does not do what he says and c) leaders should transmit the key-cultural values with reliance and evidence. 


\section{FINAL CONSIDERATIONS}

This article can preliminarily conclude that there is a paradox in the process of decision in the organization characterized by a highly complex environment and structures (HRO). Since it is a maintenance department with peculiar characteristics (high exposure to accidents, risks and crises), the bureaucratic structures, according Mintzberg (1995), require strict operational procedures in an attempt to reduce changes in behavior and actions of the individuals and risks in decision-making. Accordingly, the complex environments stimulate the specialization of technicians who, in bureaucratic structures, have less power of creativity and decision. With regards to the actions evoked in the study, rules and standards are not always important or used to solve the problems (in some cases, other types of memory were searched). Decision-making became individual or environmental, out of the established standards (procedural). In many studied tragedies, human action was decisive to the extent that these facts reached, indicating the need for mechanisms to reduce the access to nonprocedural memories in such organizations. Accordingly, there is another paradox: by limiting creativity and freedom in these departments (maintenance departments), the creative power necessary for the survival of the areas with fewer resources will be inhibited. The line that divides common sense is very faint and excess rigidity or its loosening seems to be an indication of crisis.

In highly competitive environments, such as the automotive, fast reactions are expected during unexpected events. The decrease in errors seems not to be possible in machine bureaucracies without a strong ethical commitment by the leaders, the development of more flexible structures that allow a suitable individual action and communication and demand for the expected behavior from the employees during unexpected events. This article shows the need for in-depth studies into the characteristics that would pattern the moment of the individual decision-making and their consequences to the organization during the crises.

\section{REFERENCES}

Agência Estado (2004). Plataforma P-36. Retrieved 27 outubro, 2004, from http://www.estadao.com.br/agestado/noticias/2001/mar/15/275.htm

Associação Nacional dos Fabricantes de Veículos Automotores - ANFAVE (2004). Relatório Anual. São Paulo, SP. Retrieved 20 setembro, 2004, from http://www.anfave.com.br

Burgoyne , M. (2003). Organizações Aprendizes. In C. Argyris, \& C. L. Cooper (Orgs.). Dicionário Enciclopédico de Administração. São Paulo: Atlas.

Castro, N. A. (1993). Impactos sociais das mudanças tecnológicas: organização industrial e mercado de trabalho. São Paulo: Programa de Apoio ao Desenvolvimento Científico e Tecnológico Fundação Getúlio Vargas.

Chatman, J. A., \& Cha, S. E. (2003, Summer). Leading by leveraging culture. California Management Review. University of California, 45(4), 20-34.

Croasdell, D. T. (2001, Winter). It's role in Organizational Memory and Learning. Indiana: Information Systems Management.

Cunha, M. P., \& Cunha, J. V. (2000). Improvisação e organização. In Rodrigues, S. B., \& Cunha, M. P. (Orgs.). Estudos organizacionais : novas perspectivas na administração de empresas: uma coletânea luso-brasileira. São Paulo: Iglu. 
Deming, W. E. (1980). Qualidade: a revolução da administração. Rio de Janeiro: Marques-Saraiva.

Downs, S. (2001). Mistakes in Learning: effects on the older trainee. United Kingdom: Industrial Training Research Unit.

Folha Online. Acidente com o submarino Kursk. Retrieved 27 outubro, 2004, from http://www1.folha.uol.com.br/folha/mundo/kursk.shtml

Garcia-Marques, T. (2000). Cognição Social: Contribuições para o Estudo do Comportamento Organizacional. In S. B. Rodrigues, \& M. P. Cunha (Orgs.) Estudos organizacionais: novas perspectivas na administração de empresas: uma coletânea luso-brasileira. São Paulo: Iglu.

Hodge, B. J., Anthony, W. P., \& Gales, L. M. (1996). Organization theory: a strategic approach (5a ed.). New Jersey: Prentice Hall.

Instituto de Estudos para o Desenvolvimento Industrial - IEDI (2004). Carta $n^{\circ}$ 107. Retrieved 12 julho, 2004, from http://www.iedi.org.br

Ishikawa. K. (1998). Controle de qualidade total: a maneira japonesa (6a ed.). Rio de Janeiro: Campus.

Izquierdo, I. (2004). A arte de esquecer. Rio de Janeiro: Vieira\&Lent.

Lima, C. L., Nascimento, P. M., \& Cavalcante, R. (2002, setembro). Fornecedores da Ford: uma avaliação preliminar das oportunidades de investimento na Bahia. Bahia: Estudo Setorial Desenbahia.

Machado-da-Silva, C. L., Fonseca, V. S., \& Fernandes, B. H. R. (2000). Cognição e institucionalização na dinâmica da mudança em organizações. In S. B. Rodrigues, \& M. P. Cunha, M. P. (Orgs.). Estudos organizacionais: novas perspectivas na administração de empresas: uma coletânea luso-brasileira. São Paulo: Iglu.

March, J. G., \& Simon, H. A. (1975). Teoria das organizações (2a ed.). Rio de Janeiro: FGV.

Mintzberg, H. (1995). Criando organizações eficazes: estruturas em cinco. São Paulo: Atlas.

Morgan, G. (1996). Imagens das organizações. São Paulo: Atlas.

Pike, J., \& Barnes, R. (1996). TQM in action - a practical approach to continuous performance improvement (2a ed.). London, UK: Chapman \& Hall.

Pfeffer, J. (1997). New directions for organization theory: problems and prospects. New York: Oxford University Press.

Robbins, S. P. (1999). Comportamento organizacional (8a ed.). São Paulo: Ltc.

Senge, P. (1998, julho/agosto). As cinco disciplinas. HSM Management, (9), pp. 82-88.

Sherwood, D. (2000, Autumm). The unlearning organisation. business strategy review. London Business School, 11(issue 3), 31-40.

Shingo, S. (1996). O sistema Toyota de produção: do ponto de vista da engenharia de produção (2a ed.). Porto Alegre: Artes medicas. 
Sholtes, P. R. (1992). Time de qualidade: como usar equipes para melhorar a qualidade. Rio de Janeiro: Qualitymark.

Weick, K. E., \& Sutcliffe, K. M. (2001). Managing the unexpected: assuring high performance in an age of complexity. San Francisco: Jossey-Bass. 